\title{
Mapping Histories of Art Education In New South Wales
}

\author{
Chris Peers
}

This article examines the historical discourse relating to the field of art education in New South Wales from the nineteenth through to the late twentieth century. While discussing antecedent historiography relating to the history of art education in Australia, it argues that the tasks associated with that history are incomplete. By focusing on the system of art education in New South Wales, the paper refers to the differences between specific state-based systems of art education in Australia. It indicates the advantages of recognizing the effect of sexual, ideological, psychological, and other social and educational practices when writing historical material about art education. It introduces evidence that some of the most common perceptions of the history of Australian art education require more detailed scrutiny.

Cet article présente une analyse du discours historique concernant le champ de l'éducation en arts en Nouvelles Galles du Sud, depuis le XIX ${ }^{\mathrm{e}}$ siècle jusqu'à la fin du $\mathrm{XX}^{\mathrm{e}}$ siècle. Faisant état de l'historiographie touchant l'histoire de l'éducation en arts en Australie, l'auteur soutient que cette historiographie présente des lacunes. En mettant l'accent sur le système d'éducation en arts en Nouvelles Galles du Sud, le texte fait référence aux différences entre des systèmes étatiques particuliers d'éducation en arts australiens. Il souligne les avantages à reconnaître l'influence des pratiques d'ordre sexuel, idéologique, psychologique ainsi que social et éducatif lorsqu'il s'agit d'écrire l'histoire de l'éducation en arts. Arguments à l'appui, il montre que certaines des perceptions les plus répandues de l’histoire de l'éducation en arts en Australie requièrent une analyse plus fouillée.

This article re-examines the nature and direction of the historiography of art education in Australia, and focuses on the writing of history about art education in the state of New South Wales (NSW). In particular, I trace one aspect of this historiography, by considering a perception that one of two instructional models for art education has been dominant in the Australian art classroom: either the British colonial approach known as the South Kensington school, or a second model, commonly understood to have superseded it, which incorporates modern approaches to the cultivation and development of "child art” based on the work of Franz Cizek. 
"Child art" has been characterized retrospectively by art educators as a sign of the modern era in education. Classic descriptions of child art show scenes of children engaged in finger painting and "free" applications of paints and crayons on paper, and “crude" representations using stick-figures. ${ }^{1}$ In contrast, the South Kensington regime is usually understood as imitative exercises in which students copy a series of geometric and heavily stylized ornamental line-drawings. Evidence about these two systems is drawn from archival records of the New South Wales education system - the largest of six colonial systems to emerge in Australia during the nineteenth century. The records reveal that another approach to "child art," one that was not based on the work of Franz Cizek and that led the way for the introduction of concepts of child creativity, had been adopted in NSW in the early 1900s. This approach corresponded to the work of Thomas Ablett and Ebenezer Cooke in England at the end of the nineteenth century.

Art educational debates in the second half of the twentieth century have continued to be dominated by various concepts and theories of creativity - of the child or of the artist. I trace some of the origins of these concepts as they functioned in early art educational discourse in NSW. Existing historical perspectives, I suggest, are inaccurate in portraying the sequence of development of art education in Australia as following a simple trajectory. Further, I argue that the conventional historical view in which either the South Kensington school or Cizek's “child art” model predominates is not necessarily a reliable framework for understanding the history of art education in Australia.

My investigation, which employs a form of (psychoanalytic) discourse analysis ${ }^{2}$ that aims to expose systems of meaningproduction within the historical evidence, examines the history of the meanings ascribed to art in NSW educational discourse, and involves attention to the specific identities constructed between signifiers emergent in the textual evidence. The analytic method reveals meaning within these identities, and my research here focuses on the question as to whether art is identical to creativity. Since this particular identification is so common in NSW at the

1 Cf. Viktor Lowenfeld and W. Lambert Brittain, Creative and Mental Growth (New York: Macmillan, 1975, first published 1939); Jacqueline Goodnow, Children's Drawings (Oxford: Fontana/Open Books, 1977).

2 Jacques Lacan, Ecrits (New York: Routledge, 1977); Luce Irigaray, This Sex Which Is Not One (Ithaca: Cornell University Press, 1985), 78-80, and To Speak is Never Neutral (New York: Continuum, 2002). 
beginning of the twenty-first century (for instance, few would adopt the notion of "imitative" arts in preference to "creative" arts) it seems reasonable to ask about the origins of this construct. I consider those instances where such identifications have been applied differently, and ask whether other meanings might have been excluded. Further, I link this system of meaning-production to both philosophical and psychological discourses, arguing that concepts of "child art" have been generated in accordance with phallocentric values culminating in the preservation of an opposition between imitation and creativity, on the basis of entrenched identifications between pre-eminent intellectual faculties such as imagination and invention, and masculinity. To be precise, what is prized in the NSW art classroom has been established in accordance with a code in which authorship, originality, and inventiveness are opposed to imitation, copying, and a general lack of imagination. My analysis also reveals that this opposition between the presence or absence of creativity was initiated through identifications between creativity and masculinity, corresponding to identifications between the absence of creativity and femininity.

\section{The discourse of NSW art educational history}

The identification of "child art," and of notions of creativity in children, with the modern era in art education has resulted in part from beliefs about the chronological sequence through which "child art" is said to have followed from earlier models that were less concerned with the child's special needs, abilities, and interests. Historical discourse has frequently shown that the general sequence of development of art instruction and school drawing curricula during the nineteenth century, in Englishspeaking countries such as Britain, the United States of America, Canada, New Zealand, and Australia, owes a considerable debt to the British art education regime commonly referred to as the South Kensington school. Writers such as Chalmers and Stankiewicz have variously described the nature of this debt, while explaining the degree to which the systems of art instruction in former British 
colonies ultimately diverged from the model that they inherited. ${ }^{3}$ This task of refining the historical picture so as first, to explain the origins of a given approach to art education, and second, to indicate the specific direction taken by an art education community, has been relatively neglected in the context of New South Wales.

Indeed, as Andrew Elliot has pointed out, those attempts that have been made to provide such historical research about NSW have mostly stemmed from generalizations about the nature and direction of art education in Australia as a whole. ${ }^{4}$ For instance, Doug Boughton arguably neglects to distinguish the peculiarities of different state systems of art instruction throughout the country. ${ }^{5}$ In a wide-ranging discussion of Australian art education, Boughton refers to different social, technological, economic, and political factors affecting educational policy debates in the late twentieth century, and implies that these factors have combined to thwart the realization of a unified national approach to art curricula. ${ }^{6}$ For his historical commentary, Boughton draws largely on arguments presented by Geoff Hammond and Les Mandelson which refer to systems in the Australian states of Victoria, New South Wales, Western Australia, and Tasmania, ${ }^{7}$ and adds his own mainly anecdotal evidence about NSW, so as to offer broad conclusions about three "phases" in Australian art education. The latter sequence - "hand-eye" training, which refers to the South Kensington system, followed chronologically by "creativity" or "child art" between the 1920s and the 1950s, and finally by the "studio discipline" phase from the 1960s onward - covers Australian art education from the nineteenth century through to the 1980s. It supplies the basis for Boughton's argument that, in historical terms, the various state systems of Australia were

3 Graeme F. Chalmers, "South Kensington in the Farthest Colony," in Framing the Past: Essays on Art Education, ed. D. Soucy and M. A. Stankiewicz (Reston, Va.: National Art Education Association, 1990), 70-85; Mary Ann Stankiewicz, "Drawing Book Wars,” Visual Arts Research 12 (Fall 1986): 59-72.

4 Andrew Elliot, "Continuity and Change in New South Wales, Syllabuses in Art Education,” in Papers: Occasional Seminar in Art Education 7: The Reinvention of Practices and Content, ed. A. Weate (Sydney: The University of New South Wales, College of Fine Arts, School of Art Education, 1997), 21-33.

5 Doug Boughton, "The Changing Face of Australian Art Education: New Horizons or Sub-Colonial Politics?” Studies in Art Education 30, 4 (1989): 197-211.

6 Ibid., 204-10.

7 Geoff Hammond, “Art Education Ideologies: Current Emphases in Australia," Journal of the Institute of Art Education 5, 3 (1981): 83-93; Les Mandelson, "From Drawing to Art in Australian State Schools," Journal of the Institute of Art Education 9, 1 (1985): 35-45. 
gradually converging in their approach to art education, so that a distinctly "self-determined tradition" could emerge. ${ }^{8}$ The evidence supplied by Hammond and Mandelson, on which Boughton draws, supports this conclusion by attempting to represent a common trend throughout Australia in which a binary axis emerges, opposing the South Kensington regime to the modern arrangements within which notions of "child art" and "creativity" develop. ${ }^{9}$

\section{A division between imitation and creativity}

The historical picture of art education in NSW is sharpened considerably when additional evidence is taken into account relating to the impact of psychological discourses on concepts of teaching art to children. In his discussion of modern conceptions of childhood, Chris Jenks refers to the emergence of developmental psychology and its effect on educational discourse, particularly with respect to the work of Jean Piaget. ${ }^{10}$ Jenks argues that Piaget's theory of the maturational sequence through which children move teleologically from their state of "incompleteness" to the "completeness" of adulthood is effected through a theoretical opposition between cognitive states known as "figurative thought" and "operative intelligence.” He writes that

the child, for Piaget, is preoccupied with the repetition and highly concrete replication of object states...operative intelligence on the other hand...implies the informed cognitive manipulation and transformation of objects by a reflecting subject.

The opposition that corresponds to Piaget's perspective on maturation is characterized by Jenks as a conflict between replication and transformation, and the teleological maturing or completion of the process of human growth and development is presented as "a change from affective response to cognitive

8 Boughton, “Changing Face,” 197.

9 The sense of a binary opposition between structured and unstructured approaches to art instruction is enhanced by remarks such as this from Boughton: "it is not surprising that the elements of 'discipline' characteristic of the 'hand-eye' phase should marry with the 'expressive' qualities of the 'creativity' era," suggesting that the "studio discipline" era which is supposed to have emerged in the 1960s was a bonding of the most conspicuous elements of the two previous stages; ibid., 202.

10 Chris Jenks, Childhood (London: Routledge, 1996). 
evaluation.” The correspondence between replication and imitation, as well as that between transformation and invention, is not coincidental. Children's responses to their experience of new objects are categorized according to this sequence of change because of the "by now global and overwhelming" effects of Piagetian theory for educational discourse. But Jenks is keen to point out that Piaget's theory leads to the discrediting and devaluation of activities that fall under the concrete, figurative, and affective realm of children's play. ${ }^{11}$

This evidence contributes to the historical picture by clarifying the significance of developmental psychology for art educational debate. The historical issue being raised is about the intersection of conflicting value systems, which in various contexts led either to positive or negative characterizations of child art. Indeed, Diana Korzenik argues that the concept of the "child artist" is derived from an "adult classification" of what children are doing when they draw. ${ }^{12}$ The ebb and flow of these contradictory values become apparent when Korzenik first reminds us that notions of childish creativity can be traced to the Enlightenment writings of Jean Jacques Rousseau, and then notes that by the early twentieth century German psychologists such as Kerschensteiner were affected by a prevailing ideology of socialization which led many to believe that "children and their natural development had to be forfeited for what the [overall social] culture valued in the form of the mature stage of adult development."13

The conditions affecting the meaning of children's "creative" activities have ranged quite dramatically within the context of Western educational discourse over the past few hundred years. Confusion about childhood creativity has no doubt been compounded by the fact that it may be seen either as enshrining a special childish power, or as the early arrival of adult powers. According to Jenks, the "natural" activity of childhood has been considered either intrinsically valuable, or an essentially valueless stage that must be overcome before value can be produced. ${ }^{14}$

It is perhaps banal to observe that modern art educators have tended to exclude theoretical positions that do not privilege the

11 Ibid., 24-27.

12 Diana Korzenik, "The Changing Concept of Artistic Giftedness," in The Development of Artistically Gifted Children: Selected Case Studies, ed. C. Golomb (Englewood Cliffs, N.J.: Lawrence Erlbaum Publishers, 1995), 3.

13 Ibid., 18.

14 Jenks, Childhood, 24-25. 
benefits of art in schools, and have looked to major figures for justifications for art as a "natural” feature of children's education. Arthur Efland has referred to important influences on art educational discourse in the United States, such as Friedrich Froebel in the nineteenth century and John Dewey in the twentieth. $^{15}$ Alternatively, Laura Chapman has argued that the notion of creativity as a natural feature of childhood has itself led to the visual arts being marginalized in American schools. ${ }^{16}$ Elsewhere, Efland has suggested that art has survived in mainstream schooling because it functions within the overall school curriculum to provide the appearance of "humanistic learning" and to "vivify school life and break up the deadening routine." ${ }^{17}$ If school art stands as a signifier of humanity, it may be due to the effect of underlying presumptions about the complex links between creativity and the presumed freedom of individual thought and consciousness, which again is traceable to Enlightenment philosophy.

\section{Making meanings for art in NSW schools}

The tendency amongst art educators to rely heavily on certain well-known arguments that help to justify art in schools, also leads inexorably to a vernacular belief in a rightful place for art in schools. I argue that this "right" has been built on a restrictive view of art, channelled through a system of meaning-production that must accommodate the presence and absence of creativity in the art classroom. This system, conditioned by the conflict over the meaning of children's creative activities, has operated by distinguishing and anticipating a child's unique transformation of objects, and opposing the presence of that capacity to its lack or absence, manifest in tendencies for copying and imitation. ${ }^{18}$ The meaning of "art" is always taken to mean the same thing within this

15 Arthur Efland, "Changing Conceptions of Human Development and Its Role in Teaching the Visual Arts,” Visual Arts Research 11, 1 (1985): 111.

16 Laura Chapman, Instant Art, Instant Culture: The Unspoken Policy for American Schools (New York: Teachers College Press, Columbia University, 1982), 27.

17 Arthur Efland, "The School Art Style: A Functional Analysis," Studies in Art Education 17 (2, 1976): 41.

18 Amanda Weate, “A Genealogy of Creativity: Well-Regulated Liberty,” in Papers: Occasional Seminar in Art Education 7: The Reinvention of Practices and Content, ed. A. Weate (Sydney: University of New South Wales, College of Fine Arts, School of Art Education, 1997), 88. 
system, and when played out in the Western industrial society of NSW, creative aptitudes were always credited to males, and females were awarded a monopoly on the passive status of mimic. The presence or absence of creativity functioned as a system that provided a mechanism for distributing value to the scholastic performances of male and female students. But the functioning of this system was itself conditioned by the emergence of a threat imposed by the possibility of a teacher's interference in the creative process, and, between the early 1900s and the 1960s in NSW, it generated concepts in which school-children possessed a "natural" and inviolable capacity for creative art-making. ${ }^{19}$

Historical research about art education in NSW was initiated by Ellen Waugh's investigation of art education for elementary school students, written in $1962,{ }^{20}$ and since then art education historical discourse in NSW has consistently taken the division between South Kensington and "child art" as a foregone conclusion. Writers such as Boughton, Hammond and Mandelson have treated the decline of South Kensington methods as synonymous with the emergence of the more "correct" approaches to art education that privilege children's imagination and selfexpression, thereby contributing to a narrative in which the historical trajectory is rendered virtually complete, and posing the task of securing a unified place for art at the level of a national curriculum as the most prominent dilemma remaining for the art education community. ${ }^{21}$ This tendency to assume a rightful place for an art curriculum within mainstream schooling, and to assume a lasting definition for art in schools, discloses an introspective and ahistorical viewpoint.

My adoption of psychoanalytic strategies in this context leads me to view the task of historicizing art education through a lens in which naturalized oppositions, such as that between imitation and creativity, must be interrogated. One aim here is to reveal how an ahistorical, lasting definition for "art" has developed within Australian educational discourse. I am seeking to disrupt the naturalized "obviousness" of conventional definitions and

19 Chris Peers, "Tracing an Approach to Art Teaching: A Historical Study of an Art Education Documentary Film,” Studies in Art Education 43, 3 (2002): 264-77.

20 Ellen Waugh, "The Art Education of the Teacher Trainee for the Primary Schools of NSW" (B Arts [Honours] thesis, University of Sydney, 1962).

21 Boughton, “Changing Face,” 197. 
understandings, which effectively function to maintain the discourse and to leave the identity of art education "intact."22

\section{Early drawing instruction in New South Wales}

A re-examination of the archival evidence relating to art education practice in NSW public schools provides the immediate context for this investigation. The general aims of the South Kensington regime are illustrated by a commentary prepared by Arthur Dewhurst Riley, a British advisor to colonial governments on art and drawing education in the late nineteenth century. In an 1888 report on Australian school drawing programs written for the government of New Zealand, ${ }^{23}$ Riley advanced the view that the "faculty of imitation should be developed from the earliest stages...the eye, the mind and the hand are then at once brought into play." 24 The program generally consisted of exercises in which students would attempt to produce accurate observational drawings, tracings, or copies of geometric and ornamental line drawings, sometimes utilizing plaster casts as objects of study. Riley quoted Walter Smith, the Briton enlisted by the American state of Massachusetts to develop a program of drawing instruction during the 1870s, as saying that "the teaching of drawing is of great collateral advantage in other subjects of education. It develops the intelligence and the power of observation,” and Riley added that

regarded aright, drawing in general education is the most potent means for developing the perceptive faculties, teaching the student to see correctly...by this practice the eye is rendered incomparably more accurate; and as the eye is the most open and ready road through which knowledge passes to the mind, the full development of its powers is of no small importance at all. ${ }^{25}$

22 Irigaray, This Sex Which Is Not One, 80.

23 Office of State Records New South Wales (OSRNSW), 20/12652B, Files of the Superintendent of Drawing, Arthur Dewhurst Riley, "Technical and Art Instruction and Drawing in Primary Schools," Commissioned by the New Zealand Minister of Education, George Fisher, July 1888.

24 Ibid., 2.

25 Ibid., 2-3. 
The question of what Riley understood by the "powers of the mind" is significant in comparing the ideas that underpinned either the South Kensington regime or the "child art" that followed. The task facing Riley and others such as Walter Smith, as they understood the purpose of drawing instruction, was not so much about the inherent "thinking" power of the mind, ${ }^{26}$ or about measuring an individual's artistic capacities, as it was about facilitating the supply of skilled workmen for the manufacturing industry. At the same time, the public rhetoric used to justify the South Kensington regime by Riley and others like him did not acknowledge the reality that that regime had always struggled to attract male students but in fact catered overwhelmingly to women. ${ }^{27}$ The strict exercises that the regime imposed on drawing students were, in this sense, not meant to cultivate a power for creative originality or invention, because such capacities were the prerogative of the (male) designers whose decorative and ornamental drawings were being copied by drawing students. ${ }^{28}$ It is apparent that nineteenth-century methods of art instruction were conditioned both by class divisions and by sexual boundaries. ${ }^{29}$

During the nineteenth century the South Kensington approach to drawing instruction was not immune to debates about educational methods, and according to MacDonald, was criticized by writers such as Herbert Spencer as a "dreary discipline."30 As an evolutionary biologist, Spencer was opposed to all forms of what he perceived to be regulatory activity or interference in a child's natural evolutionary development, on the part of adults such as parents or teachers. ${ }^{31}$ It is within such remarks that the antecedents for later twentieth-century fears about art teachers "interfering" in a child's natural creative development may be found. Although Spencer's evolutionist attitudes are not explicitly in evidence within historical material relating to the Australian context, their influence on others such as Ebenezer Cooke ${ }^{32}$ did

26 Walter Smith, quoted in Riley, “Technical and Art Instruction,” 2.

27 Stuart MacDonald indicates this was mainly due to changing perceptions of what constituted a gentleman's occupation: The History and Philosophy of Art Education (London: London University Press, 1970), 173.

28 Riley, "Technical and Art Instruction," 5.

29 Korzenik, "Changing Concept," 20-21.

30 MacDonald, History and Philosophy, 322.

31 Andreas Kazamias, Herbert Spencer on Education (New York: Teachers College Press, 1966), 37.

32 MacDonald, History and Philosophy, 322. 
contribute to the development of new approaches to art education in NSW in the 1900s, as is discussed below.

Between the 1840s and the late nineteenth century, when funding increased for government schools in NSW, drawing instruction was a minor consideration that was not offered consistently in every classroom. It was available in a number of private boys' schools, ${ }^{33}$ as in those girls' schools that catered mainly to the daughters of wealthier families. ${ }^{34}$ However, since teachers in government schools were almost invariably trained as elementary tutors, the time spent on drawing and the quality of the instruction depended largely on a teacher's own interest and inclination. Perceptions of drawing and art instruction amongst teachers were strongly influenced by notions of personal ability or talent, as well as more widespread associations between art and femininity.

Once technical colleges offering art and drawing classes were established in NSW in the late nineteenth century, their programs rapidly distinguished between training for men and women. Night classes were arranged for men, so as to accommodate their assumed occupation as family breadwinners during the day, while art classes for "ladies" were restricted to day-time schedules. ${ }^{35}$ This arrangement formed an obstacle to many female elementary teachers who increasingly sought to expand their knowledge of art by attempting to enrol in night-classes that were usually intended for men. ${ }^{36}$

\section{Imagining NSW art education in the early 1900s}

Seemingly bureaucratic decisions such as the arrangement of tuition schedules had an effect not only on the administration of art education, but on the way in which the subject was popularly

33 Muriel Hilson, "Art Education in NSW, 1850s to 1930s, with particular reference to the contribution of Joseph Fowles, Frederick W. Woodhouse, and John E. Branch” (M. Ed. thesis, Canberra College of Advanced Education, 1982), 48.

34 Elizabeth Windschuttle, "Educating the Daughters of the Ruling Class in Colonial NSW 1788-1850," in Melbourne Studies in Education 1980, ed. S. Murray-Smith (Melbourne: Melbourne University Press, 1980); Noeline Kyle, Her Natural Destiny (Sydney: The University of New South Wales Press, 1986), 116.

35 NSW Department of Technical Education, A Quarter-Century of Technical Education in NSW (Sydney: William Applegate Gullick, Government Printer, 1909), 145.

36 John Branch, “Art for Boys,” Public Instruction Gazette (4 Jan. 1915): 2; Mitchell Library, MSS 2996, Isabel Mackenzie, “Notes for an Autobiography,” circa 1968, 85. 
imagined and understood. Perceptions by boys or girls (or their parents or teachers) about the utility of art and drawing as a school subject in NSW were additionally conditioned by the fact that school study was intended largely as a precursor to employment. Historical factors relating to the nature of the art world hierarchy during the nineteenth and into the twentieth centuries, ${ }^{37}$ combined with other prevailing expectations relating to the appropriate postschool occupations of either sex, led to the artistic professions in NSW being dominated by men. At the same time that women were encouraged to see art as an appropriate social pastime, they were usually expected to occupy domestic positions, or were trained in suitably "feminine" skills, such as millinery or dressmaking. ${ }^{38}$ When the NSW government in the early 1900s began preparing a school infrastructure that would supply industry with a skilled workforce, the curricula for art and drawing were divided specifically according to the sex of the student because of the contradictory ways in which the school authorities imagined that the skills advanced in either art or drawing were to be used.

For instance, McKeon remarks that the 1911 syllabus distinguishes strictly between aims as they related to either sex: "commercial drawing" was indicated as being for "boys only," while the girls' "Domestic" art course was defined so as to preclude any suspicion that female students might be trained for a professional career in fine art. ${ }^{39}$ As the syllabus stated,

It is not the intention of this course to train artists, nor is it to be expected that at the end of it any great skill will be developed. It is however, expected that every pupil will acquire some elementary knowledge of Art - both Fine and Applied. ${ }^{40}$

The forms of technical practice and historical study that constituted the respective courses for boys and girls were designed specifically to provide boys with industry skills, and girls with "lady-like"

37 Linda Nochlin, "Why Have There Been No Great Women Artists?” Women, Art and Power and Other Essays (London: Thames and Hudson, 1988), 145-78.

38 Penny McKeon, "Eighty-Five Years of School Art-History," Papers: Occasional Seminar in Art Education 7: The Reinvention of Practices and Content, ed. A. Weate (Sydney: The University of New South Wales, College of Fine Arts, School of Art Education, 1997), 40; Branch, “Art for Boys,” 1-2.

39 McKeon, "Eighty-Five Years," 43-44.

40 NSW Department of Public Instruction, Courses of Study for High Schools (Sydney: Government Printer, 1911), 70-73. 
refinement and superficial familiarity with art-historical knowledge. The underlying causes of sex-segregation were to have an impact on the status of the subject within the NSW school community. A large proportion of male students were disinclined to select art as a Leaving Certificate subject over the next few decades. ${ }^{41}$

As well, the archival evidence indicates that a binary opposition between older colonial approaches to art instruction, and the modernity and progress of "child art," is at least partly due to entrenched beliefs amongst Australian art educators about the centrality of teaching methods that are designed to encourage children to express themselves. The contradiction between "handeye" training and "child art" is itself partly a retrospective invention of later twentieth-century writers seeking to justify their own preference for approaches to instruction that privilege what is imagined to be a child's spontaneous creative drive. The South Kensington regime was universally condemned within such representations, because of a perception that child self-expression and creativity were extinguished by the rigid, "teacher-centred" approach to drawing instruction that it entailed.

\section{Historicizing an opposition between the colonial and the modern}

The systematic representation of creativity as either the presence or absence of originality, imagination, or invention has masked the constitution of a historical division between the rigid obsession with "accuracy" and "correct" drawing techniques that characterize the South Kensington school, and the harmonious freedom and unfettered creativity supposedly available through "child art." It does so by way of a rhetoric that assumes the presence of spontaneous creative powers in the child, while obscuring the correlative assumption of its absence.

Creativity can only be "anticipated" 42 if we assume a position of its absence or immaturity, a situation of portentousness, potentiality, dormancy. This portent gives form to the "present," constituting the art teacher's duty as a surveillance of the produced

41 Chris Peers, “A 'Secret Tribunal' in the History of NSW Art Education,” Australian Art Education 23, 2 (2000): 4-15.

42 Weate, "Genealogy," 88. 
artwork (a duty exemplified in texts written by school inspectors in NSW between the 1900s and the 1930s in particular, and which will be discussed in more detail below). ${ }^{43}$ This surveillance becomes an activity that ironically sees mainly passivity, absence, lack, comparative lifelessness, in which art teachers are more often looking for something that is yet to be fully achieved. It therefore stipulates recognitions of both the anticipated "creative" form and the more commonplace "lack" of creativity. Identifying creativity has relied on collapsing the meanings of objects produced at the scene of the classroom into the (often different) meanings attached to well-recognized examples of art (until the 1980s these were drawn almost exclusively from male exemplars) and not-art (provided by feminine, applied-art, craft practitioners).

The consolidation of a vernacular opposition between South Kensington and "child art" relied heavily on a repression of the art/not-art polarity that operated for male and female students at the scene of the classroom. This repression was affected most conspicuously by widespread adoption of the term "child" in reference to scholastic performances in art. The notion of "child art” obliterated sexual differences between actual examples of class work, and when it emerged in historical discourse, it concealed the sex-segregated orientation of the art curriculum itself.

In effect, this means that the whole question as to when a transition between South Kensington and "child art" actually occurred, simply complicates the task of elucidating the historical origins of "child art," because it takes the creativity of the asexual child as given, rather than as an affectation of the prevailing discourse. My analysis takes into account narrative descriptions of Australian art classrooms written during the 1960s. ${ }^{44}$ Descriptions of art instruction were provided by respected educators such as Joseph Burke, who was Professor of Art History at Melbourne University, and Isabel Mackenzie, a senior lecturer in art at Sydney Teachers College during the 1940s and 1950s. Burke referred to his astonishment at arriving in Australia from Britain in 1947 and witnessing school art lessons that retained many of the features of

43 Branch, “Art for Boys,” 2; E. H. Smith "Self-Expressive Art,” The Education Gazette (1 Aug. 1935): 223-26.

44 Historical writing on art education in NSW and Australia, such as Boughton, "Changing Face”; Hammond, “Art Education Ideologies”; Hilson, “Art Education in New South Wales”; Mandelson, "From drawing to art,” reproduced vernacular perceptions of early colonial art and drawing lessons. 
the South Kensington regime. ${ }^{45}$ Mackenzie recalled her own excitement at discovering the work on "child art" of the Londonbased art educator R. R. Tomlinson in 1935, an event that inspired her to visit England and see the new approaches to art education for herself. $^{46}$ Each of these could be taken as evidence to support Boughton's much later account, insomuch as they suggest that "hand-eye" training persisted relatively unchanged until the 1930s and 1940s.

Yet the narratives offered by Burke and Mackenzie in fact tend to compound the evidence about a transition from South Kensington to "child art," and when it is meant to have occurred. Burke's description of art education in the late 1940s in Victoria detracts from the validity of Boughton's chronology, as does Mackenzie's account of NSW in 1935 . While both Hammond ${ }^{47}$ and Mandelson variously provide support for Boughton's claims, what is more significant in assessing how these historical accounts contributed to the consolidation of a division between colonial and modernized approaches is the way that they preserve a sentiment that South Kensington constituted a conservative and lingering influence in art education in Australia. This notion was advanced by Boughton when he refers to the delay of four decades between Australia and its British or American counterparts. ${ }^{48}$ Mandelson's description of the transition is of "slow and partial" modifications characterized by "gradual and often reluctant implementation of a more child-centred approach." 49 Such remarks have served to maintain a perception that Australian educators clung to a redundant methodology for art instruction, and further, that the ultimate marriage of disciplined and undisciplined models in the "studio discipline" phase laid the basis for the achievement of an independent, self-determined, and unified policy on art education in Australian schools.

45 Joseph Burke, "Some Aspects of the Debate on Art Education in Australia," Studies

in Art Education 5 (Spring 1964): 5-11.

46 Mackenzie, "Notes,” 113-15.

47 Hammond, “Art Education Ideologies,” 84.

48 Boughton, "Changing Face," 197-98.

49 Mandelson, "From drawing to art," 35. 


\section{The origins of child art in NSW}

But the wish to portray Australian art education as the gradual merging of slightly varying approaches is thrown into doubt by evidence raised initially by another historian, Muriel Hilson. In 1982 Hilson provided an exhaustive investigation into the history of the colonial system of art instruction as it developed in NSW. ${ }^{50}$ Among other interesting matters, she refers to the work of the Superintendent of Drawing for NSW schools, John Branch, who was appointed in 1903 and continued in that position until his death in 1933. Hilson observes the link between Branch's approach to art instruction and that of the London-based art educator Ebenezer Cooke, although her comments on the matter are relatively brief. ${ }^{51}$

This link between Branch and Cooke is highly significant, insofar as it reveals that Branch was influenced by late-nineteenthcentury notions of "child art," and was bent on introducing an approach involving self-expression and creativity in NSW as early as 1906. It was at this time that Branch published the first in a series of texts designed as basic programs for elementary teachers who were required to teach art and drawing, but whose own knowledge and skills in the area were limited. ${ }^{52}$ There is in fact abundant evidence to indicate that Branch was strongly opposed to the South Kensington regime, and that from the time of his appointment he endeavoured to renovate art and drawing lessons so as to accommodate what he believed to be a spontaneous creative drive in NSW schoolchildren. In the preface to his 1906 work, Branch wrote,

The copying of drawings is discountenanced on account of the narrow and stunted value of such work. The scholastic value of drawing lies not in the copying of drawings, but in the mental processes involved in the attempt to delineate truthfully what is discovered...the youngest pupil can draw from Nature, and should be allowed to develop his inherent desire to express himself. ${ }^{53}$

\footnotetext{
50 Hilson, “Art Education in NSW."

51 Ibid, 135.

52 John Branch, Brushwork From Nature with Design (Sydney: Angus and Robertson, 1906).

53 Ibid., v.
} 
Branch introduced a new approach to art instruction derived from the work of Ebenezer Cooke, who according to Stuart MacDonald was a close associate of James Sully, a philosopher of the mind whose psychological research involved him in studies of children. ${ }^{54}$ According to MacDonald, both Cooke and Sully were inheritors of a European philosophical tradition initiated by writers such as JeanJacques Rousseau, and later by educational philosophers Johann Pestalozzi and Friedrich Froebel, which postulated the preservation of "natural" childish abilities for art and creativity. ${ }^{55}$ Sully and earlier nineteenth-century writers such as Alexander Bain and Corrado Ricci were responsible for a resurgence of interest amongst Western educators in notions of "child art."

The resemblance between Branch's work and that of Cooke and his English contemporary Thomas Ablett is established on the basis of Branch's specific adoption of brushwork as an alternative method to pencil-work and "hard outline drawing."57 Efland has referred to this innovation, as has MacDonald, who quoted Cooke's explanation of brushwork as a deliberate attempt to emulate the "freedom, precision, and beauty" available through brushwork in both Greek and Japanese styles. ${ }^{58}$ Similarly Branch refers explicitly to "specimens of fine and applied art left to us by those who might be termed the artistic ancients" and declares that

it is evident that the Greeks, at least, were masters of the brush, and probably learned to draw by its means. The Japanese use the brush for line and mass, but the line is nearly always placed after the mass [brushmarks] has been made. ${ }^{59}$

Brushwork was seen by Ablett, Cooke, and Branch as a way of departing from the imitative conventions of ornamental and geometric line-drawing. Despite the fact that some of Branch's own examples of suitable forms of nature drawing and brushwork may seem, from a twenty-first-century perspective, to closely

54 MacDonald, History and Philosophy, 325. For E. Cooke, see "Our Art Teaching and Child Nature,” Journal of Education (Dec. 1885/Jan. 1886): 462-65/12-15. For J. Sully, see Studies of Childhood (London: Longmans, Green and Co., 1895).

55 MacDonald, History and Philosophy, 320.

56 Ibid, 324-25. For A. Bain, see Education as a Science (London: Kegan Paul, Trench, Trubner, and Co., first published 1878, tenth edition 1902).

57 MacDonald, History and Philosophy, 326-27.

58 Ibid., 326, Arthur Efland, A History of Art Education (New York: Teachers College Press, Columbia University, 1990), 139.

59 Branch, Brushwork, 4. 
resemble the observational studies typical of the South Kensington school, there were evidently quite radical elements of the new approach, which its adherents prized as offering a modern, psychologically informed methodology. Both Cooke and Sully discussed a maturational sequence of children's drawings observed at different developmental stages. Sully provided a model for twentieth-century psychological interests in children's drawings, and referred explicitly to his concept of the "child as artist." 60 Cooke reproduced both Sully's and Ablett's philosophies with his 1886 condemnation of the South Kensington regime:

Teach from nature, and heed its teachings also. Beware of loss of enthusiasm. Let not the aim at technical skill stagnate the intellect. Do not copy merely, but originate, invent, educate...[Mr Ablett] felt and suggested that early art, the child's ways, and nature were related, and would assist each other. Mr Ablett is seeking and suggesting a science of teaching drawing based on nature, including the child's. ${ }^{61}$

\section{John Branch's interest in “child art”}

Like Cooke, Branch also rehearsed the classic psychological fascination with the stages through which young children proceed in learning to represent the world around them through drawings, but he hastened to warn teachers in NSW that although "in early childhood imitation is an important faculty...there is a time in each child's life when it commences to think and to do in some original manner." 62 The reference to "originality" is significant. In remarks that are clearly distinguishable from Riley's 1888 promotion of the importance of imitative exercises, Branch was placing responsibility firmly upon the teacher to "give the child the power to describe his ideas and assist him to develop his inherent power." ${ }^{\text {"3 }}$ The inference made here was to a power for the production or invention of original artistic forms. Branch's

60 Sully, Studies of Childhood, 298.

61 Cooke, "Our Art Teaching," 462. Cooke’s remark about a "science of teaching drawing" indicates his defence against charges of "sentimentality" from other commentators, as well as signalling his own consciousness of the cutting-edge, modern, and scientific image that he and his colleagues sought for their new methods.

62 Branch, Brushwork, 5.

63 Ibid. 
methods were clearly intended to achieve an abandonment of the South Kensington regime, and he commenced a debate within the NSW educational community that at certain points caused friction with his colleagues in other related disciplines.

For instance, in 1917 a series of exchanges between Branch and the Inspector of Manual Training, Donald Fraser, were recorded in memoranda to the Chief Inspector for the NSW Department of Education. Here Branch sought to defend himself against a call from Fraser that "there must be a partial return to drawing from the copy to ensure greater accuracy and dexterity in drawing objects." ${ }^{4}$ Manual Training consisted of preparatory tuition in metal-working and wood-working trades, lessons which entailed frequent reference to technical drawings. But learning to make such drawings had previously been undertaken in boys' drawing lessons, which Branch was in the process of transforming into studies of art. In his reply to Fraser, Branch went to considerable pains to explain the minimum necessary time that teachers ought to be devoting to art and drawing lessons, and added that

no return to drawing from a copy would enable boys to draw an object better. Art is a human expression and one educative value lies in its power to compel the child to see, observe and investigate...in the days when copied work was used in our schools the results were almost valueless. If we even permitted "partial return to drawing from the copy" we should have some teachers spreading the partial return over the whole work. $^{65}$

Much of the concern expressed by Branch in his response to Fraser resulted from his own apprehension of an ongoing bias against the new drawing curriculum amongst male students and male teachers. In an earlier 1915 commentary, Branch had explicitly promoted art as a "boy's subject" and remonstrated with the "man teacher" who had "not troubled to attend the evening classes in Art that the women have been attending in such vast

64 OSRNSW 20/12654, Files of the Superintendent of Drawing, Memorandum initialled by the Chief Inspector of NSW Schools, addressed to the Superintendent of Drawing, 28 Mar. 1917.

65 OSRNSW 20/12654, Files of the Superintendent of Drawing, Memorandum signed by John Branch, 30 Mar. 1917. 
numbers during this last decade.” 66 According to Branch, this lack of interest on the male teacher's part had resulted in male students not being informed of the importance of art and of the links between drawing lessons and a range of "highly paid" male professions. He declared defiantly that "the greatest painters, goldsmiths, sculptors, designers, architects, weavers, dyers, etchers, lithographers, engravers, and decorators have been men and are yet men." ${ }^{6}$ His argument here illustrates the impact of a prevailing preoccupation with the purpose of schooling, as providing students with skills that would be of continuing use for their post-school occupations.

Like Cooke, Branch did not identify the innovations to drawing curricula using the term "child art." The central aims of these new approaches were affected as much by psychological theory as by commonly held beliefs about the social roles of men and women. On one hand, it was precisely because of widely prevailing beliefs in a conflict between art and masculinity that South Kensington methods continued to be seen as an important and useful component of boys' education by individuals such as the Inspector for Manual Training. Yet other evidence suggests that the very notions of inventiveness, originality, and "inherent" or spontaneous "power" for description that had been adopted by Branch in the early 1900s were ultimately taken as the basis for "child art" by later educators, such as Branch's successor as Superintendent of Drawing for NSW schools, Edward Healy Smith. As has been noted, creativity was often signified in terms that provided a correlation with the sort of masculine skills and intellectual faculties important to the occupations and professions with which boys were expected to identify. ${ }^{68}$ "What would be useful to the manufacturers" supplied a common refrain within this discourse, conditioning the recognition of originality, inventiveness, imagination, and self-expression. The principles that were central to Branch's approach to art education, and which were frequently promoted by him as essentially masculine attributes, were eventually recognised by NSW teachers as comprising the structure of a child's natural creative instinct.

66 Branch, “Art for Boys,” 1.

67 Ibid.

68 Chris Peers, "A Homo-sexual Ideology in the History of New South Wales Art Education,” Pedagogy, Culture and Society 10, 1 (2002): 5-20. 


\section{The emergence of the creativity model in NSW}

According to Mandelson, the transition from "hand-eye training" to "child art" in Australia was led during the 1920s by Western Australian educational authorities. Mandelson asserts that "states other than Western Australia and Tasmania operated as if the new concepts of child art did not exist" until after an important conference was held in 1937 by the New Education Fellowship, attended by a range of international educational speakers. ${ }^{69}$ Similarly Hammond has placed the advent of the creativity model after the Second World War, arguing that "in Australia, words such as 'self-expression,' 'imagination,' 'interest,' 'freedom,' 'enjoyment' were not part of the normal vocabulary of art educators until the 1950s and early 1960s.",70

Boughton's assertion that the creativity model arrived in Australia "after World War One... [and that it was] largely due to the ideas of the Austrian Franz Cizek" ${ }^{\text {"71 }}$ further compounds the difficulty of establishing an accurate chronological history of art educational change in this country. In relation to NSW, Mandelson has referred to Ellen Waugh's anecdotal evidence that examples of work by Cizek's students were exhibited in Sydney in $1924 .{ }^{72}$ It seems reasonable to assume that Cizek's approach was indeed influential in many parts of the country, and there is convincing evidence to indicate that by the 1960s, many Australian art educators were persuaded either by Cizek's views, or those of later theorists such as Herbert Read and Viktor Lowenfeld, as Hammond has argued. ${ }^{73}$ For instance, Burke describes a heated debate that erupted at an art education conference held in Canberra, the Australian national capital, in 1963, in which the nature of the creativity model was at stake. ${ }^{74}$

John Branch's ongoing struggle to overcome the declining interest of male students in $\mathrm{art}^{75}$ had achieved an improvement in the subject's status by the 1930s, at least from the point of view of his successor. Appointed to the position of Superintendent of

\footnotetext{
69 Mandelson, "From drawing to art," 40.

70 Hammond, "Art Education Ideologies," 85.

71 Boughton, "Changing Face," 199.

72 Mandelson, "From drawing to art," 38.

Hammond, "Art Education Ideologies," 85.

Burke, "Some Aspects," 6-7; cf. Peers, "Tracing an Approach."

75 For example, see OSRNSW 20/12654, Files of the Superintendent of Drawing, John Branch, “Annual Report for 1921.”
} 
Drawing on Branch's demise in 1933, Edward Healy Smith commented that

while I feel this state is to be congratulated because drawing is firmly established in its schools, and that it is no longer the "Cinderella" it was, I also feel that valuable time and ability is lost because the drawing is all "directed" and imitative, instead of being undirected and creative. ${ }^{76}$

Smith's utilization of the division between imitation and creativity is explicit in these remarks. Like Branch, Smith went on in this text (titled "Self Expressive Art") to rehearse the classical psychological sequence through which children's drawings were expected to pass, and explicitly describes self-expression commencing among infants in the form of scribbles, comparing the child to "primitive man""77 in exactly the same way that James Sully had done in the 1890 s. $^{78}$

The remark about art no longer being "Cinderella” was made in conjunction with Smith's identification of the male student as the vehicle through which the aims of the syllabus would be achieved. ${ }^{79}$ "Cinderella" constituted a symbol of Smith's distinction between a subject that, in his perception, did what it ought to have been doing for boys, and a curriculum that was constantly struggling with an image problem stemming from the perceived "femininity" of art as a school subject. It was, in effect, Smith's way of asserting that art was no longer studied by girls alone, that it no longer lacked the basis for a higher status, and that greater numbers of boys were being taught the subject.

\section{Inventing a masculine model of creativity}

From the time of his initial instructional texts published in 1906, John Branch had advanced views about how the teacher must encourage the child to express himself, using powers of imagination and invention. ${ }^{80}$ Later discussions from 1915 signal Branch's adoption of prevailing assumptions connecting sex and

\footnotetext{
Smith, “Self-Expressive Art," 223-24.

Ibid., 223.

Sully, Studies of Childhood, 385.

Smith, "Self-Expressive Art," 224.

Branch, Brushwork, 6.
} 
artistic aptitude. While acknowledging that many female students excelled in their art classes, Branch nevertheless despaired that the lack of interest by boys in art would result in a dearth of artists. He instructed male teachers on how to recognize an artist in the boys' classes, and consistently linked artistic talent with male-dominated professions:

The ordinary free drawing lesson should be the commonest means for finding artistic talent, but there is [sic] quite a lot of artists whose talents are on the creative, inventive, or imaginative side. These are of the greatest importance to the manufacturers. ${ }^{81}$

Later still in 1921 he wrote again of the problems arising from boys not studying art, and added that "art is a man's occupation and these future manufacturers are not getting as good an education in artistic taste as their sisters who will become their customers, the buyers." 82 Branch repeatedly acknowledged the productive, valuable powers of invention and imagination when identifying the structure of a male student's talent and ability. Female students who were capable of performing well in the same subject were systematically excluded from such identifications, even if they had comparable or superior skills. ${ }^{83}$

Similarly, when Smith came to describe the valued components of "child art" and self-expression in 1935, he advanced a picture that is closely identifiable with Branch's image of the artistic male. Referring to both male and female children, he carefully distinguished what were perceived to be the natural interests of either sex as they manifested themselves in drawings and choice of subject matter. Even more conspicuously, Smith reserved the description of "artist-in-training" for male students:

These young people should be trained as artists are trained, as individuals...Train for individuality, for personality, for character, in the boy and in his work. As we have no use for artists who are like peas in a pod, so in the same manner we have no use for boys who can be turned out as automatons. Of

81 Branch, “Art for Boys,” 2.

82 Branch, "1921 Annual Report.”

83 Ibid. 
what value is uniformity to the community, have you ever thought? ${ }^{84}$

This description is reminiscent of arguments advanced by the English psychologist Cyril Burt in 1922, whose tests of artistic ability were used to suggest that boys always display innate capacities for imagination and invention, and that they prefer depicting scenes of activity, while girls were represented as invariably displaying imitative tendencies, preferring the passivity of still-life drawing. ${ }^{85}$ Smith went on to explain that art education in the modern world aimed to "afford opportunity to the child to see, feel, and express beauty in creative work, unhampered by restriction of any kind". ${ }^{86}$ The most explicit references to differences in artistic ability according to sex were gradually replaced by a neutered language of the "child,” embracing a general category of art student.

As Amanda Weate has pointed out in her commentary on the meanings of "creativity" in art education, the creative process in which the art student engages essentially "refers to the disposition of the individual as the cause of creativity...creativity is perceived in the form of anticipated and explainable moves as a kind of observable activity." ${ }^{87}$ Smith's account of self-expression and the ideal creative process as it should unfold in the art classroom was dependent on teachers explicitly identifying the signs of a creative power manifesting itself. Smith's "anticipation” of how the creative instinct would unfold in that context entailed warnings to teachers, who were perceived as a threat on the basis of their potential to interfere, against stifling creativity by "directing" the child. Hence Smith's instruction:

Creative power is a natural endowment of all mankind...no child must be induced to imitate adult ideas or technique...Technique should not be "directed" before practice begins, nor even afterwards, except a child asks for help. Give them their work and keep them at it, but let them work the subject out in their own way. ${ }^{88}$

84 Smith, "Self-Expressive Art," 224

85 Cyril Burt, Mental and Scholastic Tests (London: London County Council/P. S. King and Son Ltd, 1922), 326.

86 Smith, "Self-Expressive Art," 225.

87 Weate, "A Genealogy of Creativity," 88.

88 Smith, "Self-Expressive Art," 224. 
Smith's assertion that creative power is an endowment natural "to all mankind" should be taken literally, and this is clear from the selection of famous (male) artists to which Smith referred in exemplifying his claim. The unleashing of creative power for the sake of self-expression was a trait that Smith only identified among individual artists such as Giotto, Whistler, Degas, and the Australian Hans Heysen. The aim of Smith's advice was to prevent teachers interfering in a "natural" process of actively releasing the creative impulse, for fear that the child would be reduced to a passive and imitative state of creative "dormancy." 99

Like those of Branch, Smith's 1930s discussions provide an important foundation for the discourse of creativity in art education, establishing identifiably "male" aptitudes as the universal criteria for measuring performances of scholastic ability in art. Through the process of "naturalizing" such criteria the opposition between imitation and creativity is cemented. The system is reproduced when it is used to measure students' performances in art, and to "tell" how closely such performances approximate the "typical" positive and negative components of this artistic binary structure.

\section{Conclusion}

The opposition between creativity and imitation, and the conflict between South Kensington and child art that corresponds to it, have entered the consciousness of NSW art educators, who commonly treat them as natural counterparts. In practice, these structures have contributed to the sense of elusiveness and to the special importance attached to the task of coaxing a creative act into existence in the art classroom. In the light of my evidence that John Branch had introduced the notion of artistic self-expression into NSW art educational discourse as early as 1906, it may seem paradoxical to reflect on the fact that two influential NSW art educators, Isabel Mackenzie and Edward Healy Smith, each writing in 1935, invested great value in notions of child art and creativity, but were each convinced that the educational practices corresponding to such notions were either unavailable, or were poorly understood by teachers in NSW at the time. Their convictions were fuelled by a system of meaning-production that 
would only permit them, and later historical writers for that matter, to identify art in schools with invention, imagination, originality and self-expression.

The blinding effect of this system of meaning-production prevented them from seeing value in the most commonplace "feminine" school-art activities, which effectively constituted the NSW curriculum up until the late 1960s. Such non-art did not sufficiently approximate the exemplars of fine "art," nor did it resemble the classic finger-painting-style expressionism characteristic of "child art." Anything less than, or outside, the strict boundaries of creativity, was inadequate for their purposes, which were to promote and teach "art." My point is that these boundaries owed themselves to a hidden demand for the preservation of identities between art and creativity. The opposition between invention and imitation was an outcome of a system that needed women to lack creativity so as to guarantee a male monopoly on valued scholastic and artistic attributes.

There can be no doubt that considerable change must have occurred between 1935 and 1963, when Australian art educators came together and debated the merits of varying approaches to creativity in Australia. ${ }^{90}$ Yet the evidence also indicates that the conflict between educational regimes that, purportedly, either extinguish or cultivate a child's "natural” power to self-expression, can be dated to Enlightenment philosophy relating to the existence of free-willed, self-driven, conscious, ambitious, individual man. ${ }^{91}$ In the light of this evidence, when the ability for self-expression is constructed as a modern goal for art education, it reflects the influence of eighteenth-century attitudes. The origins of the conflict between "hand-eye" training and "child art" cannot be located essentially within the innovations of either Franz Cizek or Ebenezer Cooke, but derive from a much older desire, emanating from Rousseau, for a child unspoiled and unencumbered by the rules and expectations of adults.

Similarly, the influence of "hand-eye" training cannot be reduced to a conservative attitude born of familiarity with nineteenth-century methodologies. The South Kensington school was the earliest mass form of art education in Australia because its emergence in Britain coincided with British colonial expansion of the nineteenth-century. In a sense, it must have been represented

90 Burke, "Some Aspects," 6-7.

91 MacDonald, History and Philosophy; Weate, “Genealogy,” 87. 
as a progressive development by its British exponents, such as A.D. Riley and Walter Smith, because it functioned to enhance the skills of a working population at a time when mass schooling and instruction itself epitomized modernity and social change. The critique of South Kensington launched by John Branch in the form of an early approach to "child art" was therefore not necessarily so profoundly modern as it might seem at first glance. Insofar as it reiterated Enlightenment beliefs about a child's natural or inherent disposition for creativity, originality, and invention, it was in fact an agency of conservatism itself, carrying a psychologically modified ideology of the "child," and of scholastic ability, into the twentieth century. Psychological discourses can, in this sense, be seen to have influenced the art curriculum by supporting a program of normalization, supplying the explanation of the child's "nature," and helping to cement the associations between a sequence of development and the unfolding of creative "abilities" in "the child."

Thus, the process of naturalizing the opposition between South Kensington and "child art" is revealed as an outcome of historiographical introspection. Theories of art education cannot afford to assume the place of art in schools as "given," as if it inhered within a naturally occurring phenomenon known as creativity, but must investigate the historical basis on which meanings and functions for art in schools have developed. The opposition between imitation and creativity as it relates to the South Kensington/child art binary has itself militated against the emergence of any other, alternative explanations for the historical aims of art curricula. This binary has functioned hegemonically to restrict the meaning of art in schools to an opposition between stultifying exercises in copying and imitative drawing, and the paradigm of "child art" in which the creativity of art students is represented by way of more-or-less muted comparisons with the most famous, mythologized, and invariably masculine exemplars of the Western "high" art tradition. Art educational debate, of which historical enquiry is one form, has been dominated by this system of meaning-production, which can be disrupted, however, when the historical evidence relating to the origins of this binary is examined.

The intersections of beliefs about sex and intelligence, and about the function of art and drawing to demonstrate mental as well as technical faculties that have been consistently identified from a phallocentric perspective, underpin the discourses of art education in NSW. It is not so much that historians in Australia have simply overlooked these factors, but that the values contained within the 
discourse itself may be exposed as having the power to reduce the historical evidence to a series of seemingly obvious and unremarkable "truths." The need for debate about the meaning of historical material relating to the field of art education in Australia is clearly ongoing. 